\title{
Methodology for the Semi-quantitative Evaluation of Geoheritage Applied to Coastal Geotourism in João Pessoa (Paraíba, Northest Brazil)
}

\author{
Luciano Schaefer Pereira ${ }^{1}$ (D) Daniel Matos de Carvalho ${ }^{2} \cdot$ Lúcio Sobral da Cunha $^{3}$
}

Received: 12 November 2018 / Accepted: 4 October 2019/Published online: 23 October 2019

(C) The European Association for Conservation of the Geological Heritage 2019

\begin{abstract}
In this work, a new methodology is presented for the semi-quantitative evaluation of the coastal geotouristic potential and protection requirements of ten sites chosen in the coastline of the State of Paraíba, about $54 \mathrm{~km}$ from the state capital. The geotouristic potential was determined based on two indicators, whose value was estimated: the Touristic Use Potential, with ten variables, with different levels of importance, and the Additional Value, with six variables, also with different levels of importance. The Need for Protection Index was estimated taking into consideration ten variables with different levels of importance and based on the need to protect the sites once the geotouristic activity starts to generate impact in the places where it is implemented. The Imminent Risk Index applied to the sites where the level of vulnerability is greater was calculated based on the Need for Protection Index, with a weight of 1, and the Touristic Use Potential and Additional Value Index, which added also present a weight of 1 . The result of the simulation done to the area was satisfactory, making it possible to apply in other areas, as long as the necessary adjustment measures to the local context are taken into consideration.
\end{abstract}

Keywords Semi-quantitative evaluation $\cdot$ Coastal Geotourism $\cdot$ Geoheritage $\cdot$ Paraíba

\section{Introduction}

Tourism is a secular activity; however, due to the developments, it has undergone in recent years, most of them associated with natural aspects; it has never been in the spotlight as much as it is

This article is part of the $\mathrm{PhD}$ project in Physical Geography at the University of Coimbra.

Luciano Schaefer Pereira

1schaefer2@gmail.com

Daniel Matos de Carvalho

danielmatosc@hotmail.com

Lúcio Sobral da Cunha

luciogeo@fl.uc.pt

1 Center of Human Sciences and its Technologies, Federal Institute of Education, Science and Technology of Paraíba, $1^{\circ}$ de maio, 720, 58015-020 João Pessoa, Brazil

2 Federal Institute of Education, Science and Technology of Paraíba, João Pessoa, Paraíba, Brazil

3 Department of Geography, Faculty of Letters, University of Coimbra, Coimbra, Portugal today. Rural tourism, ecotourism, adventure tourism and geotourism are some of the examples of segments that have renewed this activity, increasing incomes, moving capital, improving the quality of life of the populations involved and, when executed in a sustainable way, prolonging the life of the environment and assisting in its preservation. This development has created new territories, in which every spatial element that is possible to be inserted into the touristic dynamics is welcomed. In this context, geotourism, by inserting geoheritage into the touristic activity, generates different physical areas of appreciation, or causes old ones to be seen with a fresher perspective. The rocks, their minerals, their tectonic deformations, the fossils, the reliefs, the soil, the water, among others, are some examples of the elements that have increased this touristic area.

Therefore, geotourism is a new segment that aims to appreciate, promote and value the geological and geomorphological heritage, or geoheritage, as a whole, including forms and processes (Dowling 2011), adding the abiotic environment to the elements of fauna and flora, while using geoheritage in a sustainable way. The pioneering definitions involving the term "geotourism" date from the mid-1990s, starting with Hose (1995, 2000). Geoheritage can then be described and interpreted in places with relevant aspects that promote its 
interpretation, always with the objective of benefiting the local community and introducing environmental awareness to the elements involved. It is important to note that, in this work, geoheritage corresponds to the abiotic portion of Natural Heritage, which can be subdivided into Geological, Geomorphological, Pedological and Hydrological Heritage (Rodrigues and Fonseca 2008). The role of geotourism is to disseminate the geodiversity of places through its geoheritage, with the implementation of projects of scientific, educational and interpretative purposes that promote tourism in the area.

The touristic flow of João Pessoa is very low, in the Brazilian context, when compared to that of Natal and Recife, nearer capitals, respectively located north and south. According to data from the Statistical Yearbook of Tourism (2013), prepared by the Ministry of Tourism, 620 thousand passengers landed at "Castro Pinto" Airport in Bayeux, in the metropolitan region of João Pessoa, against 3.2 million in Recife and 1.3 million in Natal. At the regional level, only Teresina performed worse, with 527 thousand passengers in the same year.

Although it possesses a singular scenic beauty, when the moment comes for tourists to select a northeastern capital to visit, João Pessoa has been continuously relegated. Thus, the effort to add the abiotic environment to tourism is essential as an attempt to increase this activity in the capital. There are some methodologies in the literature directly applicable to this type of use of geoheritage (as we'll see soon) and the objective of this work is to propose a semi-quantitative evaluation methodology of the geotouristic potential of João Pessoa and of the southern coastline of the State of Paraíba, up to the "Abiaí" Depression, about $50 \mathrm{~km}$ from the state capital.

The mapping of the geological typology of the Historic Centre is incipient (Pereira et al. 2013a, b; Pereira and Amaral 2014), the same happening with the geoheritage of the area involved: currently the topic of study of the doctorate in Physical Geography of the first author, in the University of Coimbra, Portugal.

\section{Area of Study}

The municipality of João Pessoa is the capital of the state of Paraíba, the most eastern part of Brazil. In fact, João Pessoa is known worldwide as the "eastern end of the Americas", which, by itself, provides it with touristic potential. Its geographic coordinates are $7^{\circ} 7^{\prime} \mathrm{S}$ and $34^{\circ} 53^{\prime} \mathrm{W}$ and the proximity of Ecuador provides it with high temperatures throughout the year. It has an area of $211.5 \mathrm{~km}^{2}$ and a population of 723.515 inhabitants (Brazil 2010), resulting in a demographic density of 3421 inhabitants $/ \mathrm{km}^{2}$, the highest in the state. As well as the capital, the southern coastline receives an important touristic flow in its beaches, with buggies being one of the main means of transport, which are rented in packages sold in kiosks located in the main urban beaches.

Being a coastal city, its natural landscape is essentially littoral, selling tourists an image of "sun and sea". The great estuary of the Paraíba River, which in its lower course flows parallel to the coast, is separated from the sea by an enormous scrubland. The river then forms fluvial beaches, which have become important touristic spots, like the one of "Jacaré", whose sunset to the sound of Ravel's Bolero is a must-see together with the mangrove ecosystem that stretches for tens of kilometres.

To exemplify the natural geotouristic potential of the city, in addition to the geomorphosite described above, we can mention the "Cabo Branco" cliff (on the beach of "Seixas", the most eastern point of the Americas), the natural pools of "Tambaba" Beach, formed in the dead water tides from the outcrops of the sandstone reefs that touch the beach, the Love Stone, which corresponds to a rare limestone outcrop of the "Maria Farinha" Formation that, through marine abrasion, eventually formed a heart-shaped cavity, "Irerês" Lagoon, popularly known only as the Lagoon (in the heart of the city, it corresponds to a dolina), the "Coqueirinho" Canyon that, despite its name, is in fact a large and beautiful voçoroca (land collapse) open in the "Barreiras" Formation, the Holocene and Pleistocene marine terraces, important testimonies of paleo-geographic and coastal dynamics, the coral reefs of "Picãozinho", among others.

In the last decades, the population increase of the municipality has resulted in a greater anthropic action on this natural landscape, which corresponds to an environment that interweaves coastal, valley and plain areas. Despite being a capital, the passage from urban area to rural area, in its periphery, is made abruptly, displaying a provincial character, with forests and mangroves being mixed with asphalt, pollution and people. Sugarcane plantations and small rural farms observe from a distance the rapid evolution of this urban site.

\section{Geological and geomorphological context of the area}

The area is located in the topographic chart of João Pessoa plane (SB-25-YC-3), scale 1:100,000, elaborated by the Army Ministry. The geology of the research area is associated with Paraíba sedimentary basin. Such sediments were deposited as the South American continent withdrew from the African continent (Françolin and Szatmari 1987), over a crystalline basement deformed by shear zones (Jardim de Sá 1994). This basin can be subdivided into three sub-basins (Fig. 1): Olinda, Alhandra and Miriri sub-basins. The study area is part of the Alhandra sub-basin, border to the north by Itabaiana fault and to the south by Goiana fault. 
Fig. 1 Location Area (circle) in the sedimentary basins of the Northeast. (Source: modified from Barbosa and Lima Filho 2005)

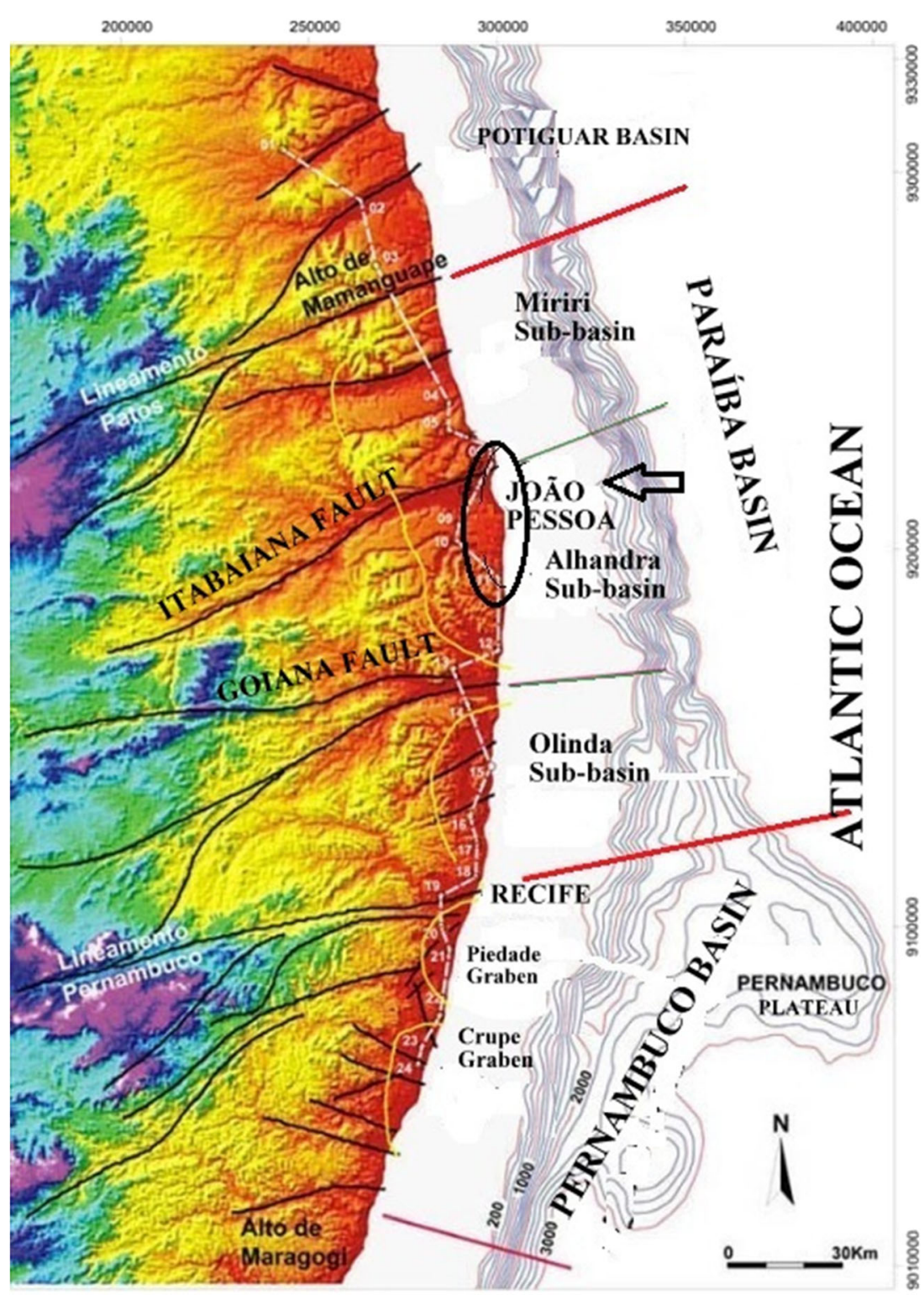

The geological substrate of João Pessoa is marked by sediments that date from the end of the Triassic period to the present (Asmus 1975), on a crystalline basement called "Terrain Alto Moxotó" (orthogneisses and granite suites) that does not appear in the area. From the sedimentary sequence, we highlight the "Itamaracá"/"Beberibe" Formation (base, siliciclastic), "Gramame"/"Maria Farinha" (centre, carbonate) and "Barreiras" (platform cover), as well as quaternary sediments representative of a marine-transitional environment, all of them modelled and remodelled by exogenous agents, especially the fluvial and marine agents, resulting in a unique geoheritage.

From the Pliocene, as a result of the establishment of a stress field in the South American plate, with compression oriented E-W and N-S extension, a series of faults that hit the overlapping sediments were reactivated, having a crucial role in coastal morphology and tracing of the hydrographic network (Bezerra et al. 2001).

The research area belongs to the geomorphologic unit of Plains and Coastal Tablelands, according to Ross (1985), having direct relation with ancient tectonic movements, generated during the drift of the South American and African plates (Asmus 1975), added to Cenozoic tectonic events (Bezerra et al. 2001). We can identify three subunits to the urban site of João Pessoa and the south coast: the coastal plain, low coastal upland ("Coastal Tablelands") and floodplains, which can be still subdivided into fluvial and fluvial-marine floodplains (Rodriguez 2002).

The top of the tablelands is linked to the plains in relatively steep slopes, in the form of cliffs, with great scenic beauty, in the shore. The coastal lowlands are in direct contact with the sea, have altitudes between 0 and $10 \mathrm{~m}$, which quaternary 
sedimentation of river, marine and rivermarine origin filled the coastal plain, resulting in numerous geomorphological features that can be considered potential geomorphosites for its scenic beauty and/or relevant geological/geomorphological history. On the margin of the Paraiba River, floodplains occur on higher altitudes, whose presence of mangroves, away up to $12 \mathrm{~km}$ of the coastline denote its ecological importance. In the northern portion of the study area, the sandbank of Cabedelo ("Restinga de Cabedelo") separates the Paraíba River from the Atlantic Ocean. The low coastal uplands, also known as "Coastal Tablelands", correspond to a higher, gently sloping portion of the land, with flat top, generally inclined to the east, result from the action of exogenous agents that carved the Barreiras Formation, including marine abrasion on cliffs, another outcrop form of this formation on the coast, at its eastern portion. Most of the urban site of João Pessoa sits on this geomorphological unit.

According Brito Neves et al. (2004), these low coastal uplands were results of large arching and a succession of steeped pediplains to inland, subordinated to paleoclimate, whose graben-horst-type structure controlled its morphology. Reactivation of basement shear zones with E-W ansd NESW direction, from the Early Cretaceous (Nóbrega et al. 2005), reach the sediments of the Barreiras Formation, forming fault scarps that are capped by alluvial terraces, sandstone dunes, debris slopes, soil and vegetation, and which serve as bounds of the river valleys, while the upraised portions were dissected (Lima et al. 1990).

Thus, the altimetric quotes of the urban compartment of tablelands show uplifted portions (west, whose elevations reach $70 \mathrm{~m}$ ) and lowered portions (between Mumbaba River and Sanhauá River, a tributary of the Rio Paraiba, where altitudes do not exceed $40 \mathrm{~m}$ ), rising again (in the upper course of the Rio Cuiá), decreasing toward the east, and denoting the structural behavior of the graben-horst type, bounded by normal faults (Bezerra et al. 2001). The substrate of municipality is represented by a Graben, called Gráben da Grande João Pessoa, according Brito Neves et al. (2004), whose sediments reach $300 \mathrm{~m}$ thick, when they reach the basement.

The criterion for choosing the sites was according to the presence of values, such as cultural, scientific, aesthetic, ecological, among others, and Fig. 2 shows the location of the sites in the area. These values were considered as parameters for the calculation of the Geotouristic Potential of the geosites.

\section{Semi-quantitative evaluation methodology of geotouristic potential}

Geoheritage, particularly geological and geomorphological heritage, has been semi-quantitatively evaluated since the pioneering work of Grandgirard (1995). Since then, several authors have proposed methodologies for the quantitative evaluation of geoheritage, with the purpose of doing the inventory and quantification of the geodiversity of the sites, of the potential of certain sites to be classified as geosites/ geomorphosites or of the level of vulnerability to which these sites are subjected.

Inserted in these proposals, we mention Rivas et al. (1997), Lima (2008), Gacia-Cortez and Carcavilla (2009), Pereira (2010), Fassoulas et al. (2012), Figueiró et al. (2014), Brilha (2015), among others. For these authors, the mapping of geoheritage mainly aims at its geopreservation or the promotion of geosciences to a larger public. In this sense, geotouristic activities would serve as an additional tool to achieve this goal. However, mapping the geotouristic potential of these sites was not the main guideline for these methodologies. Theoretical-methodological proposals of semiquantitative evaluation of the geotouristic potential of geosites and geomorphosites are scarce in the literature. However, a highlight should be given to the precursor work of Pralong (2005), who, in addition to the quantification of the touristic potential of sites, in the case of geomorphological sites, assessed the risks of exploring these sites in a tourist and recreational context, using as case study two mountainous areas of the Alps, Chamonix-Mont Blanc, in France and Crans MontanaSierra, in Switzerland. According to the author, this touristic potential can be quantified using four main values: scenic/aesthetic, scientific, cultural/historical and economic/social, each divided into several attributes, which were scored from 0 to 1 , according to some previous works. After Pralong (2005), we cite Rybár (2010), Pereira and Pereira (2012), Pereira and Nogueira (2015), Ziemann and Figueiró (2017), Brazilian Geological Service (CPRM), among others.

In the case of the latter, CPRM developed an application for the automatic registration and quantification of geosites, called GEOSSIT, being one of the first Brazilian initiatives that enables the integration of data from the inventory records and quantification parameters for characterization of national geological heritage. It works as a tool for standardizing the registration of geosites in Brazil, from free access to visualization of existing sites. For the quantification of vulnerability and didactic, scientific and touristic values, GEOSSIT used the method of Gacia-Cortez and Carcavilla (2009), maintaining all parameters and their respective weights for the calculation of the final value.

The semi-quantitative assessment of the geotouristic potential of João Pessoa and the southern coastline of Paraíba, the baseline of this article, corresponds to an intermediate phase of the promotion process involving other sequential phases (Brilha 2005), namely: identification (In which geoheritage segment can the site be inserted? Geological, geomorphological, pedological or hydrological?); inventory (creation of a database with the heritage elements, with the completion of descriptive files, containing various information, such as absolute location, means of access, photographic register of the 
Fig. 2 Location of the assessed geosites in the area

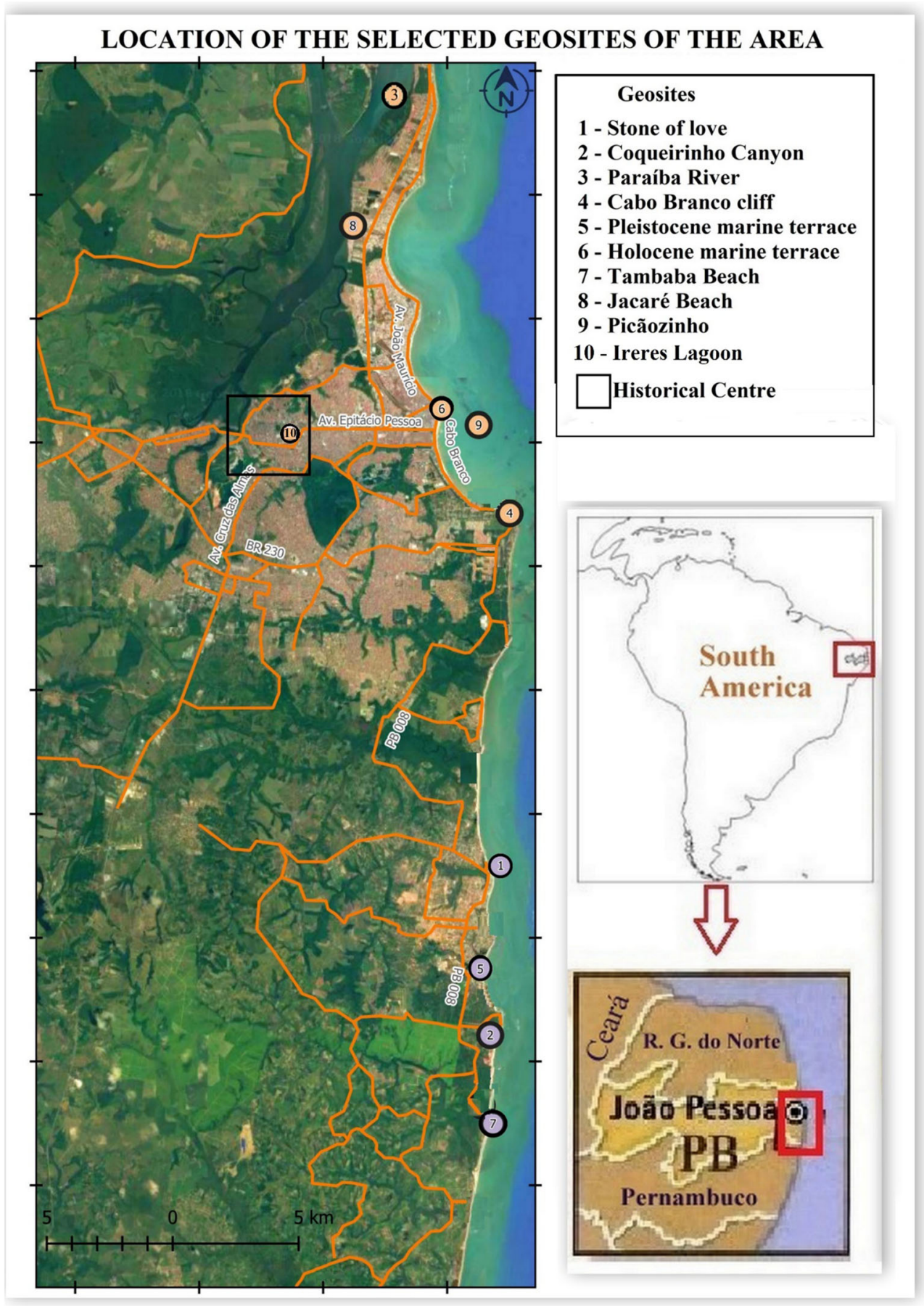

site, a detailed description of geological, geomorphological, pedological and hydrological features, considering the scale of the site, from the outcrop to the landscape); semi-quantitative evaluation (degree of importance of the element for geotourism, as well as the evaluation of the degree of vulnerability, aiming at the creation of geoconservation measures, based on the proposal of this work); and promotion (publicity of the value of heritage elements, through the elaboration of the geotouristic guide of the area and other promotion methods). This integrated methodology will be published soon.

Between December and February of the years 2014 to 2017, 237 questionnaires were given to tourists who participate in a tour through the southern coastline of the State of Paraíba, which had the duration of about $7 \mathrm{~h}$ and covered several sites of geotouristic interest in order to know the profile of the tourist in a geotouristic context. This questionnaire discriminated the places visited and the tourists had to make 
an evaluation of the spots that marked their tour, demonstrating their perception of the landscapes and sites visited.

These tourists did not know concepts such as geotourism $(59 \%)$ or geoheritage $(51 \%)$, but were interested in understanding how the natural landscape of the area was formed $(87 \%)$, and felt the absence of panels, posters or geointerpretative boards in the area (77\%).

Based on the profile of the area's tourist, obtained from the questionnaires carried out and presented, we are able to classify the visitors of João Pessoa and the southern coastline of Paraiba as "type 1", according to Miller (1991), "general tourist" (sensu Hose 1995, 2000) and "interested visitor" (sensu GRANT 2010), since they are unaware visitors of the geotouristic activities and concepts that involve geoheritage, and this is not the main motivation for their choice of travel destination. However, these tourists made it clear that they were curious to understand the dynamics of the landscape, and not only to appreciate it, as well as comprehend the interest of the abiotic heritage, especially in what regards the beach, the sea and the landform.

Thus, the methodological proposal of this work emphasizes the criteria that stimulate the geotouristic use of the sites mapped in the quantification of this potential, giving less importance to the scientific, ecological and cultural values, which were used as parameters to calculate the "Additional Value", and giving more importance to the aesthetic value and the indicators of the degree of tourist support that are at the base of the estimation of the "Touristic Use Value".

Different weights are attributed to the indicators of each criterion, valuing those that make the difference for a better understanding of the criterion, be it touristic or additional. These criteria were partially based on the models of quantitative evaluation presented by Uceda (1996), Brilha (2005) and Gacia-Cortez and Carcavilla (2009), to which were added some new indicators based on the local reality.

The methodology proposed here is based on the obtaining of three indices: two secondary indices (Geotouristic Potential and Vulnerability) and a general index (Imminent Risk Index-IRI), obtained by weighing the values of the two secondary indices. These indices were obtained from the authors' completion of two files containing the variables and their respective weight in the estimation. For this, it was necessary a detailed knowledge of the physical (geology, geomorphology, hydrology and pedology), socioeconomic, touristic and ecological characteristics of the catalogued sites. This knowledge was acquired in the preliminary phases of bibliographical research and field mapping.

\section{Geotouristic Potential}

The Geotouristic Potential (GeoP) is a result of the evaluation of two central characteristics: Touristic Use Potential (TUP), which combines variables that characterize elements of aesthetic value and touristic support (Table 1) and the Additional Value - AdV, in which a combination of scientific, ecological and cultural values is highlighted (Table 2).

Considering these variables and after the calculation of an average is done, the Geotouristic Potential Index-TPI and the Additional Value Index-AdVI, respectively, with the first indicator having a double weight in the calculation of the GeoP in relation to the second. Thus, Tables 1 and 2 describe the variables selected to calculate the indicators, the weight of the variable, the score associated with the mapped location (ranging from 1 to 5) and the degree of importance of the variable (weight). For a better understanding of these variables, the reading of Pereira and Nogueira (2015) is recommended.

Therefore, the GeoP, the Tourist Use Potential Index-TPI and the Additional Value Index - adVI should be obtained as follows:

$\mathrm{TPI}=\left(\sum_{i=1}^{10} T U P_{i} *\right.$ Weight $\left._{i}\right) / 100$

$a d V I=\left(\sum_{i=1}^{10} a d V_{i} * W_{e i g h t}\right) / 50$

where TUP $_{\mathrm{i}}$ is the variable $\mathrm{i}$ of Touristic Use Potential, $\mathrm{adV}_{\mathrm{i}}$ is the variable $i$ of the Additional Value, and Weight $t_{i}$ is the weight of variable $i$.

The Geotouristic Potential (GeoP) will be estimated by adding the result of these two indicators, divided by 3 , to reach a value between 1 and 5 , as in:

$G e o P=(\mathrm{TPI} * 2+a d V I) / 3$

It should be noted that each indicator received different weights. The construction of the indicators was based on the concept of a pondered average, where we consider the response of the variable, weighted by the degree of importance of the variable, divided by the sum of the weights.

As mentioned previously, the result of the three indicators will be between 1 and 5 . If two or more sites have similar GeoP values, the site with the highest TPI, which has a higher weight in the GeoP calculation, is considered as a tie-breaking criterion.

As a standard scale of the quality of the GeoP, a scalar grid can be implemented to allow a quick perspective over the behaviour of the sites in the study (Fig. 3), where

$\checkmark$ GeoP with values between 1 and 2: sites without geotouristic potential.

$\checkmark$ GeoP with values between 2.01 and 3: sites with weak geotouristic potential.

$\checkmark$ GeoP with values between 3.01 and 4: sites with good geotouristic potential.

$\checkmark$ GeoP with values between 4.01 and 5: places with high geotouristic potential. 
Table 1 Quantification variables of Tourist Use Potential (TUP) of the catalogued sites, with their respective weights

Local characteristics

Aesthetic value

TUP $_{1}$ - spectacularity/beauty

5. Very high visual and scenic quality

4. High visual and scenic quality

3. Average visual and scenic quality

2. Low visual and scenic quality

1. Very low visual and scenic quality

$\mathrm{TUP}_{3}$ - colour contrast at the site

5. At least five contrasting colours

4. Four contrasting colours

3. Three contrasting colours

2. Two contrasting colours

1. Identical colours

Access/transport

Value of tourist use

TUP $_{5}$-access

5. Direct access using the main road

4. Access partially done through paved secondary road

3. Access partly done through paved secondary road while the other part is done on non-paved road

2. Access partially done through unpaved secondary road

1. Access requires the use of boat

Tourist support

Value of tourist use

$\mathrm{TUP}_{7}$ - distance from the nearest town

5. Within a large city, with at least 100

thousand inhabitants.

4. Nearest town at least $5 \mathrm{~km} /$ marine site

3. Closest city between 5 and $8 \mathrm{~km}$

2. Closest city between 8 and $15 \mathrm{~km}$

1. Nearest town more than $15 \mathrm{~km}$

$\mathrm{TUP}_{9}$ - presence of hotel infrastructures

5. At least $500 \mathrm{~m}$ of distance

4. Between $500 \mathrm{~m}$ and $1 \mathrm{~km}$

3. Between 1 and $5 \mathrm{~km}$

2. Between 5 and $10 \mathrm{~km}$

1. More than $10 \mathrm{~km}$

Total weight
Weight 20

$\mathrm{TUP}_{2}$ - presence of non-harmonic elements (nhe)

5. Absence of nhe in the landscape

4. Weak impact of nhe

3. Average impact of nhe

2. Strong impact of nhe

1. Nhe interfere in a very significant way in the landscape

Weight 5

$\mathrm{TUP}_{4}$ - clarity

5. Easily visible at least $1 \mathrm{~km}$ away

4. Visible at least $500 \mathrm{~m}$

3. Only visible between 100 and $500 \mathrm{~m}$

2. Only visible between 10 and $100 \mathrm{~m}$

1. Only visible less than $10 \mathrm{~m}$ away

Weight 10

TUP $_{6}$ - transport

5. Easily reached by motor vehicle

4. Partially reached by motor vehicle and on foot-walking at least $100 \mathrm{~m}$

3. Reached partially by motor vehicle and on foot-walking between 100 and $500 \mathrm{~m}$

2. Partially reached by motor vehicle and on foot-walking more than $500 \mathrm{~m}$

1. Only reached by boat

Weight 10

$\mathrm{TUP}_{8}$ - promotion

5. Broad promotion by specialized media

4. Great promotion

3. Average promotion

2. Weak promotion

1. No promotion

Weight 10

$\mathrm{TUP}_{10}$ - proximity to restaurants and bars

5. At least $500 \mathrm{~m}$ of distance

4. Between $500 \mathrm{~m}$ and $1 \mathrm{~km}$

3. Between 1 and $5 \mathrm{~km}$

2. Between 5 and $10 \mathrm{~km}$

1. More than $10 \mathrm{~km}$
Weight 15

Weight 5

Weight 5

Weight 10

Weight 10

100
All sites belonging to the two upper classes will be inserted in the Geotouristic Map of João Pessoa and the Southern Coastline, a geotouristic itinerary, all the rest will be discarded. Clarity and objectivity were intended objectives in the theoretical-methodological process of semi-quantitative evaluation. However, as we were performing this exercise, it was possible to observe that a certain level of subjectivity is inherent in any quantitative evaluation methodology, since some values are intangible and/or highly dependent on the appraiser's opinion.

\section{Need for Protection Index}

Taking into consideration that the geotouristic activity generates impact where it is implemented, if not accompanied by geopreservation proposals, the Imminent Risk Index (IRI) of the sites will be calculated based on an indicator called Need for Protection (NP), subdivided into ten variables, whose score ranges from 1 to 5 , partially based on Gacia-Cortez and Carcavilla (2009), according to Table 3. Thus, we repeat the proposals done for the two previous indicators, also with different weights for each variable. The higher the values assigned to the variables, the greater the need for preservation.

The Need for Protection Index (NPI) of the site will be estimated based on the variables, each one with different weights, displayed on Table 3. For this, the formula used was:

$\mathrm{NPI}=\left(\sum_{i=1}^{10} N P_{i} *\right.$ Weight $\left._{i}\right) / 100$

Resulting in a value between 1 and 5 , where $\mathrm{NP}_{\mathrm{i}}$ is the variable $i$ of the Need for Protection and Weight $t_{i}$ is the weight of variable 1. 
Table 2 Quantification variables of the additional value (AdV) of the inventoried sites, with their respective weights

$\mathrm{AdV}_{1}$ - abundance/singularity

5. Unique in the studied area

4. There are only two similar locations

3. There are 3 to 4 similar sites

2. There are 5 to 6 similar sites

1. The place is very common

$\mathrm{AdV}_{5}$ - paleogeographic and geological interest

5. Clear and visible witness of phenomena and processes

4. -

3. Witness but not so visible

2. -

1. Low importance or uninteresting

Ecological value

$\mathrm{AdV}_{5}$ - ecological interest

5. Large fluvial or marine site with reefs

4. Marine river site, small/medium size river lagoon, dolinas and springs

3. River site or basically acts as a wildlife support

2. Low ecological interest

1. No ecological interest

Total weight
Scientific value

\begin{tabular}{|c|c|c|}
\hline \multirow{6}{*}{$\begin{array}{l}\text { Weight } \\
15\end{array}$} & $\mathrm{AdV}_{4}$ - degree of scientific knowledge & \multirow[t]{6}{*}{ Weight } \\
\hline & 5. More than one doctoral/master's thesis & \\
\hline & $\begin{array}{l}\text { 4. At least one doctoral/master's thesis and one article in } \\
\text { a national newspaper }\end{array}$ & \\
\hline & 3. Only a doctoral/master's thesis & \\
\hline & $\begin{array}{l}\text { 2. Publications are restricted to national scientific meetings } \\
\text { or national newspapers }\end{array}$ & \\
\hline & 1. There are virtually no publications & \\
\hline \multirow[t]{7}{*}{ Weight 5} & $\mathrm{AdV}_{6}$-representative/local type & \multirow[t]{7}{*}{ Weight } \\
\hline & 5. Stratigraphic reference & \\
\hline & $\begin{array}{l}\text { 4. It adequately illustrates a particular characteristic } \\
\text { or represents processes }\end{array}$ & \\
\hline & 3. Illustrates a particular characteristic or represents processes & \\
\hline & 2. Poor representative & \\
\hline & 1. Not representative & \\
\hline & Cultural value & \\
\hline Weight & $\mathrm{AdV}_{\mathrm{x}}$ - association with cultural elements & \multirow[t]{2}{*}{ Weight } \\
\hline 10 & $\begin{array}{l}\text { 5. Referenced in iconography (maps/plants) and historical textual } \\
\text { documents, both colonial and associated with local beliefs } \\
\text { 4. Referenced in iconography (maps/plants) and textual historical } \\
\text { documents, without association with local beliefs } \\
\text { 3. Referenced in colonial iconography or historical textual documents } \\
\text { 2. It has cultural value limited to local beliefs } \\
\text { 1. Not relevant }\end{array}$ & \\
\hline
\end{tabular}

Once the NPI is estimated, the Imminent Risk Index (IRI) is calculated, which will involve all the quantified parameters until then. The protection priority of the site will be the result of the GeoP added with the NPI, the latter with a greater weight.

In the end, the results will be ranked in decreasing order for a better perspective of the sites that need urgent protection in relation to others, whose need for protection will be directly proportional to the IRI value. The IRI will be calculated as follows:

$\mathrm{IRI}=(G e o P * 0,5+\mathrm{NPI}) / 1,5$

If two or more sites have similar IRI values, the site with the highest NPI, which has a greater weight in the IRI calculation, is considered as a tie-breaking criterion.

In the same way, the median of this sample universe is estimated and divided into classes between 1 and 5. The upper area (values between 4.01 and 5) is considered as requiring urgent care by the state; the need for protection decreases as the IRI values decline; thus, the lower class needs very low protection.

Fig. 3 Scale of the geotouristic potential of a coastal area

\section{Application of the geotouristic potential to the mapped area}

Ten sites (Fig. 4) were randomly selected to be evaluated from a much larger universe, after detailed studies of geology, geomorphology, tectonics and stratigraphy, and through information collected from published works about the Paraíba Basin. They are:

- "Cabo Branco" Cliff

- Holocene Marine Terrace

- "Coqueirinho" Canyon

- "Irerês" Lagoon

- "Jacaré" Beach

- Stone of Love

- Pleistocene Marine Terrace

- "Tambaba" natural pools

- Paraíba River Estuary

- "Picãozinho"

The main objective of this selection is to apply the methodology proposed here, through the previously mentioned formulas. The results are presented on Tables 4 and 5 . 
Table 3 Quantification variables of the Need for Protection (NP) in the catalogued sites, with their respective weights. The higher the values assigned to the parameters, the greater the need for preservation

$\mathrm{NPI}_{1}$ - anthropogenic vulnerability modality

5. Sites strongly altered by human action, with great possibility of destruction in the short-term

4. Sites strongly altered by human action, with possibilities for long-term destruction

3. Sites that, even with intense anthropization, will hardly be destroyed due to their isolation

2. Small to medium-sized sites that suffer from small human influence and small deterioration.

1. Large sites that suffer little human influence and small deterioration.

$\mathrm{NPI}_{3}$ - monthly number of visitors in high season (December to February)

5. More than 10 thousand visitors

4. Between 5 thousand and 10 thousand visitors

3 . Between 1 thousand and 5 thousand visitors

2. Between 500 and 1 thousand visitors

1. Less than 500 visitors

$\mathrm{NPI}_{5}$ - protection regime

5. Does not present any legal protection level

4. Partially included in a protected area with allowed visitation

3. Partially included in a protected area with restricted visitation

2. Totally included in a protected area with allowed visitation or isolated from human action

1. Totally included in a protected area with restricted visitation

$\mathrm{NPI}_{7}$-real estate pressure

5. Distance less than $50 \mathrm{~m}$ from some construction/allotment

4. Distance between 50 and $500 \mathrm{~m}$ of some construction-allotment

3. Distance between $500 \mathrm{~m}$ and $1 \mathrm{~km}$ of some construction-allotment

2. Distance between 1 and $5 \mathrm{~km}$ of some construction - allotment or isolated from human action

1. Distance greater than $5 \mathrm{~km}$ from some construction/allotment

$\mathrm{NPI}_{9}$ - surface extension

5. Over 50 thousand $\mathrm{m}^{2}$

4. Between 20 thousand and 50 thousand $\mathrm{m}^{2}$

3. Between 10 thousand and 20 thousand $\mathrm{m}^{2}$

2. Between 1 thousand and 10 thousand $\mathrm{m}^{2}$

1. Less than 1 thousand $\mathrm{m}^{2}$

Total weight
Weight $20 \quad \mathrm{NPI}_{2}$ - natural vulnerability

5. Affected by active processes of high intensity

(marine abrasion, floods, mass movements, among others)

4. Affected by active processes of medium intensity

3. Affected by active processes of low intensity

2. Affected by active processes of very low intensity

1. Vulnerable only to chemical weathering

Weight $15 \mathrm{NPI}_{4}$ - settlement proximity

5. Within an urban nucleus with more than 50 thousand inhabitants.

4. Within an urban nucleus with more than 50 thousand inhabitants, with at least $10 \mathrm{~km}$ of dense area

3. Within an urban nucleus with less than 50 thousand inhabitants.

2. Distance between 10 and $50 \mathrm{~km}$ of an urban/marine nucleus

1. Distance greater than $50 \mathrm{~km}$ from an urban core or isolated from human action

Weight $10 \quad \mathrm{NPI}_{6}$ - associated economic activities

5. Quarries and urbanization

4. Sand extraction and direct tourist activities on the site

3. Bars and restaurants and indirect tourist activities near the site

2. Low-impact human activity

1. No economic activity

Weight $5 \quad \mathrm{NPI}_{8}$ - level of deterioration

5. Very high deterioration, which strongly masks the original characteristics of the local site

4. High deterioration

3. Average deterioration

2. Low deterioration

1. No deterioration

Weight $5 \quad \mathrm{NPI}_{10}$ - property regime

5. Private land belonging to several owners

4. Private land owned by an owner

3. Partially public and private land

2. Predominantly municipal land

1. Predominantly state-federal land
Weight 10

Weight 5

Weight 15

Weight 10

(1)

Weight 5
Considering the results obtained, with respect to the geotouristic potential (GeoP) of the sites mapped, and separating them, as proposed, in areas, we have the situation displayed in Fig. 5a. Regarding the Imminent Risk Index (IRI), the ranking resulted in the configuration of Fig. $5 \mathrm{~b}$.

\section{Discussion of the results obtained}

Recently, through the interviews conducted to 602 tourists that visited João Pessoa and the region, between December 26,
2013, and January 15, 2014, the "Fecomércio" Institute of Economic and Social Research of Paraíba - IFEP (IFEP 2014) came to the conclusion that the "Cabo Branco" Cliff, with its lighthouse, the "Jacaré" Beach, the "Picãozinho" and the "Coqueirinho" Canyon are among the most visited touristic spots in the region, while the urban beaches (in descending order, "Tambaú", "Cabo Branco", "Manaíra", "Bessa" and the beaches of "Cabedelo") were the ones selected to be visited. Immediately following, the preference falls upon the southern coastline, with "Coqueirinho" and "Tambaba" standing out.

When we associate the spots selected by the tourists, sampled in the IFEP survey, with the results obtained by the semi- 
Fig. 4 Aerial and surface photos of the assessed sites: a Stone of Love (source: photo of the author (s), 2014); b "Coqueirinho" Canyon (source: photo of the author (s), 2016); c Estuary of the Paraíba River (source: Newsea, 2015); d "Cabo Branco" Cliff (source: photo of Elda Karoline, 2016); e Pleistocene Marine Terrace at "Tabatinga" Beach (source: photo of the author (s), 2014); f Holocene Marine Terrace at "Tambaú" Beach (source: photo of Ricardo Paulo, 2005); $\mathbf{g}$ "Tambaba" natural pools (source: source: photo of Thiago Farias, 2006); h Sunset at "Jacaré" Beach (source: photo of the author (s), 2016); i "Picãozinho" (source: Brasilvip, 2014); j "Irerês" Lagoon (source: Guia Mais, 2015)
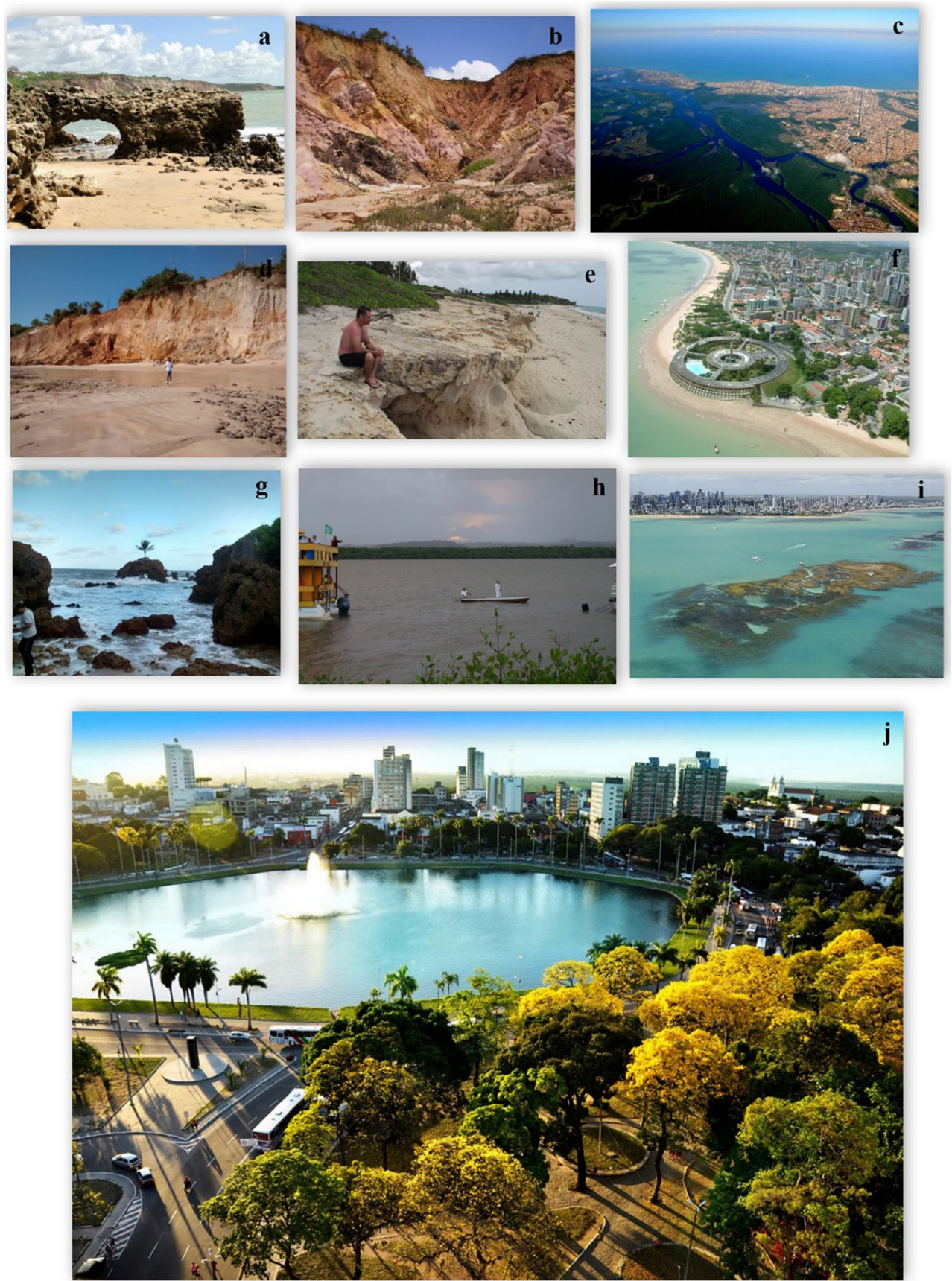

quantitative evaluation methodology of the geotouristic potential, the results are curious. Together with the Holocene marine terraces, the "Irerês" Lagoon and the "Cabo Branco" Cliff are the only sampled sites with high geotouristic potential. The "Cabo Branco" Cliff, for example, is signalled as the "most eastern point in the Americas" and this slogan is sold to the world, although this location is really at the "Seixas" BeachPonta do Seixas. From this cliff, there is a spectacular view of the municipality of João Pessoa and its beaches_- "Cabo Branco", "Tambaú", "Manaíra" and "Bessa", from the south to the north. At the back of these beaches, there is the geomorphosite of the Holocene marine terraces that, due to their magnitude and high occupation rate, present a serious need for protection, as well as the highest geotouristic potential of all sites. The "Cabo Branco" Cliff has its natural landscape completely modified, suffering from a high degree of deterioration due to human occupation and adjacent buildings, such as the Science Station. It has the differential of an intense marine erosion on its slopes, which resulted in its partial collapse in April 2015, as well as part of a cliff attached to it.

The "Irerês" Lagoon, in the heart of the Historic Centre of João Pessoa, stands out for its scenic beauty, as well as its 
Table 4 Results of the semi-quantitative evaluation of the selected sites in João Pessoa and the Southern Coastline

\begin{tabular}{|c|c|c|c|c|c|c|c|c|}
\hline Potential site & Main heritage segment & Thematic category & TPI & AdVI & $\begin{array}{l}\text { TPI/ } \\
\text { AdVI }\end{array}$ & GeoP & NPI & IRI \\
\hline "Cabo Branco" Cliff & Geomorphology & Coastal geoform & 4.75 & 3.1 & 1.53 & 4.2 & 3.95 & 3.97 \\
\hline Stone of Love & Geomorphology & Karstic & 3.4 & 3.55 & 0.96 & 3.45 & 3.25 & 3.32 \\
\hline Holocene Marine Terrace & Geomorphology & Coastal geoform & 4.75 & 3.45 & 1.38 & 4.32 & 4.05 & 4.14 \\
\hline Pleistocene Marine Terrace & Geomorphology & Coastal geoform & 2.65 & 3.1 & 0.85 & 2.8 & 3.25 & 3.1 \\
\hline "Coqueirinho" Canyon & Geomorphology & Pluvial geoform & 3.9 & 3.25 & 1.2 & 3.68 & 3.45 & 3.52 \\
\hline "Tambaba" natural pools & Geology & Marine & 3.8 & 4.35 & 0.87 & 3.98 & 2.6 & 3.06 \\
\hline "Irerês" Lagoon & Geomorphology & Karstic geoform & 4.75 & 3.45 & 1.38 & 4.25 & 3.6 & 3.82 \\
\hline Estuary of the Paraíba River & Geomorphology & Fluvial-marine & 4.2 & 3.4 & 1.23 & 3.93 & 3.7 & 3.78 \\
\hline "Jacaré" Beach & Geomorphology & Fluvial & 4.0 & 3.45 & 1.16 & 3.82 & 3.20 & 3.41 \\
\hline "Picãozinho" & Geomorphology & Marine & 3.5 & 3.65 & 0.96 & 3.55 & 2.7 & 2.98 \\
\hline
\end{tabular}

ecological, paleo-environmental-geological-geomorphological and historical importance, with records in sixteenth century iconography.

The estuary of the Paraíba River, which bathes the extremely populous João Pessoa, and other cities in the metropolitan region, such as Santa Rita, Bayeux and Cabedelo, where anthropization is intense, has resulted in an ecosystem with forms of relief that are extremely sensitive to deterioration. Their IRI assessment was inserted in the average need for protection. This is where "Jacaré" Beach is located, one of the most visited places by tourists with the existence of commercial establishments and bar-restaurants, until then in stilt construction - since these made the environment susceptible to the risk of deterioration, they were removed from this site, hence its average classification regarding the need for protection.

On the other hand, although it is inserted in the area of good geotouristic potential, "Picãozinho", one of the most visited tourist spots in the capital of Paraíba, had the third lowest GeoP. This result can be justified by the low score, from the point of view of geotouristic use value that the geomorphosite received in the categories of "access" and "transport", since it can only be reached by boat, and "clarity", since it is located about $2 \mathrm{~km}$ from the beach of "Tambaú". This same geomorphosite, regarding additional value, has received low scores in "association with other cultural elements", because of its geographical isolation, and in "degree of scientific knowledge", essentially restricted to the community of Biological Sciences, which study the reef ecology and its fauna and flora. The only site with low geotouristic potential was the Pleistocene Marine Terraces. Their TPI/AdVI ratios were the lowest of all mapped sites, which highlights the importance of the additional value of these sites in relation to geotourism. "Picãozinho", although fragile and susceptible to deterioration, was the only site inserted in the area of low protection needs, mainly due to the low values that it receives in "protection regime" and "property regime", since both are under legal protection and with restricted visitation. Through the Normative Instruction no. 138, of 2006, of the Brazilian Institute of the Environment and Renewable Natural
Table 5 Results of GeoP and IRI, ranked in decreasing order

\begin{tabular}{llll}
\hline Site & GeoP & Site & IRI \\
\hline 1. Holocene Marine Terrace & 4.32 & 1. Holocene Marine Terrace & 4.14 \\
2. "Irerês" Lagoon & 4.25 & 2. "Cabo Branco" Cliff & 3.97 \\
3. "Cabo Branco" Cliff & 4.2 & 3. "Irerês" Lagoon & 3.82 \\
4. "Tambaba" natural pools & 3.98 & 4. Estuary of the Paraíba River & 3.78 \\
5. Estuary of the Paraíba River & 3.93 & 5. "Coqueirinho" Canyon & 3.52 \\
6. "Jacaré" Beach & 3.82 & 6. "Jacaré" Beach & 3.41 \\
7. "Coqueirinho" Canyon & 3.68 & 7. Stone of Love & 3.32 \\
8. "Picãozinho" & 3.55 & 8. Pleistocene Marine Terrace & 3.10 \\
9. Stone of Love & 3.45 & 9. "Tambaba" natural pools & 3.06 \\
10. Pleistocene Marine Terrace & 2.8 & 10. Picãozinho & 2.98 \\
Median & 3.875 & Median & 3.46 \\
\hline
\end{tabular}


Fig. 5 a Quality Scale of the geotouristic potential for the surveyed area. $\mathbf{b}$ Scale of the Imminent Risk Index in the sampled sites of the area

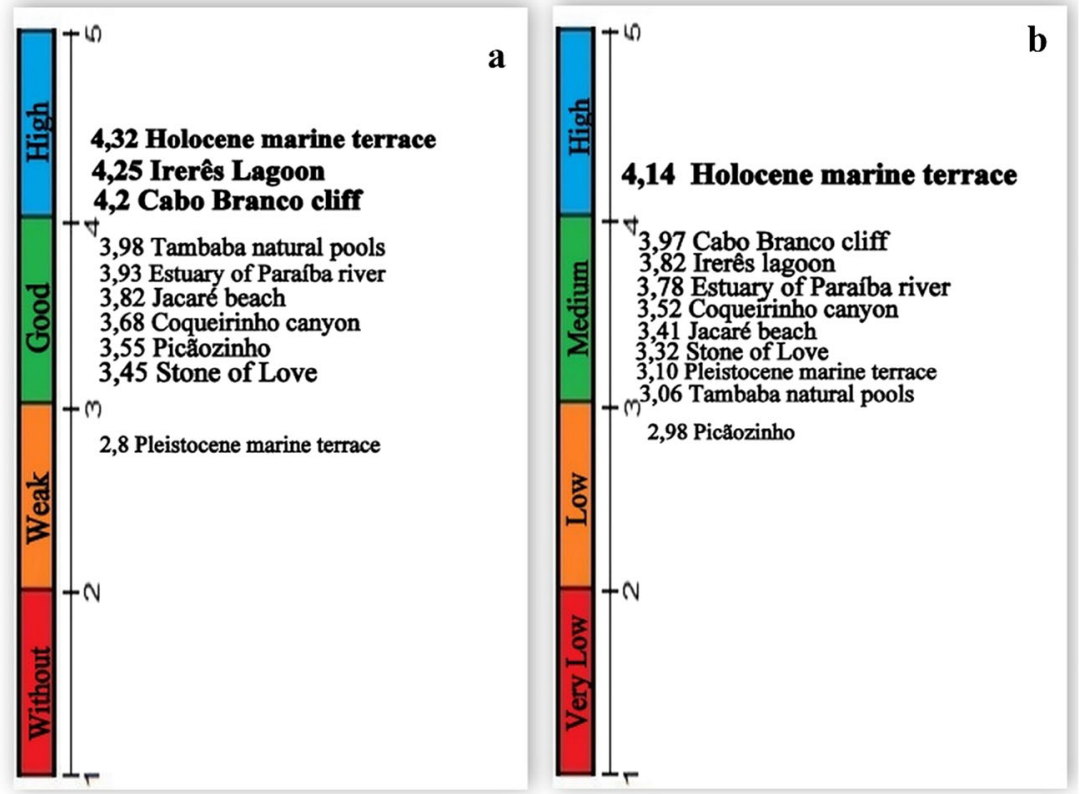

Resources (IBAMA), its algae coral reefs are protected from extractive activities in areas of greater fragility.

\section{Conclusions}

The geotouristic potential of João Pessoa and the southern coastline is evident, but its confirmation through its semiquantitative evaluation is still lacking. Thus, this work specifies a quantitative evaluation model, using as primary criteria the geotouristic value and the additional value of ten sites and places of interest, which were randomly selected. Once these are quantified and ranked, this proposal will allow the creation of a geotouristic guide for the region and the implementation of promotion methods for this geoheritage, such as folders, posters and signs, distributed along this itinerary in the sites with the highest geotouristic values. In addition, the protection value was considered, based on the knowledge of the protection needs of each mapped location, being pertinent for the planning of a territorial preservation management that effectively protects the most threatened areas.

Comparing the results obtained by this methodology with the practice, where several of the sites are effectively points of high tourist visitation, the results, for some points, converged, for others not, like "Picãozinho". This can be explained as the criteria used in the estimation of geotouristic potential are different from those used by conventional tourists.

According to data from the IFEP (2014), the main reason for tourists to visit João Pessoa was its beaches (57\%), while only $5.5 \%$ answered that they were interested in the natural landscape. As pointed out earlier, a questionnaire was distributed between December 2014 and January 2017, and, among the basic questions included, there were the tourists' perception of the natural landscape, the semi-quantitative evaluation of some of the sites visited on the tour, and terms as "geological heritage", "geomorphologic" and "geotourism". From here, the tourist profile through the geotourism bias was known, being classified as "type 1" according to Miller (1991), "general tourist" (sensu Hose 1995, 2000) and "interested visitor" (sensu Grant 2010).

We can conclude that, even though it is a recent segment, not sufficiently promoted, particularly in Brazil, geotourism should be understood as a new asset to be introduced in the tourism market. Geotourism will help in the revitalization of the stagnant economy of the area in question, generate income and employment and provide the education of local population for the geopreservation of the abiotic environment, which serves as a resource for geotouristic attraction and the promotion of local geodiversity and geosciences.

The presence of a pre-existing tourist itinerary in the area facilitates the incorporation of the geotouristic points of observation in its structure, which provides additional value to the activity that is in a lower position when compared to the neighbouring capitals, even if its geodiversity is as exuberant as theirs is.

This methodology, after being tested and despite possessing a certain degree of subjectivity, proved to be a useful and effective form of semi-quantitatively evaluating the geotouristic potential of the places of interest, having been elaborated for the coastal region of Paraíba. It is possible to apply this method to other areas, as long as its indicators are adapted to the local reality.

Acknowledgments The authors would like to thank CAPES for funding the scholarship, process no. 11988/13-4, CAPES - Ciência Sem 
Fronteiras program and the Centre for Studies in Geography and Spatial Planning (CEGOT) for the support regarding the translation costs.

\section{References}

Asmus HE (1975) Controle estrutural da deposição mesozóica nas bacias da margem continental brasileira. Rev Bras Geoc 5(3):160-175

Barbosa, J, Lima Filho, M (2005) Os domínios da Bacia da Paraíba. In: Congresso Brasileiro de P\&D em Petróleo e Gás, 3, Salvador. Anals. [Rio de Janeiro]: Instituto Brasileiro do Petróleo, 20051 CD-ROM

Bezerra FH, Amaro V, Vita Finzi C, Saadi A (2001) Pliocene- quaternary fault control of sedimentation and coastal plain morphology in NE Brazil. J S Am Earth Sci 14:61-75

Brazil (2010) Instituto Brasileiro de Geografia e Estatística, Dados do censo. http://www.ibge.gov.br/catálogos/indicadores. Acessed 15 Jan 2012

Brilha J (2005) Património Geológico e Geoconservação, a conservação da natureza na sua vertente geológica. Palimage Editores, Braga

Brilha, J (2015) Inventory and quantitative assessment of Geosites and Geodiversity sites: a review. Geoheritage, Review Article, published online at 15 th January 2015. http://link.springer.com/. Acessed 11 July 2015

Brito Neves BB, Riccominni C, Fernandes TM, Sant'ana LG (2004) O sistema tafrogênico terciário do saliente oriental nordestino na Paraíba: um legado proterozóico. Rev Bras Geoc 34(1):127-134

Dowling RK (2011) Geotourism's Global Growth. Geoheritage 3:1-13

Fassoulas C, Mouriki D, Dimitriou-Nikolakis P, Iliopoulos G et al (2012) Quantitative Assessment of Geotopes as an Effective Tool for Geoheritage Management. Geoheritage 4(3):177-193

Figueiró, AS, Vieira, A, Cunha, L et al. (2014) Proposta de classificação de patrimônio geomorfológico com vistas a construção de um banco de dados luso-brasileiro. Poster session presentation at the I Lusobrazilian meeting of Geomorphological Heritage and Geoconservation, Coimbra. Portugal

Françolin JB, Szatmari P (1987) Mecanismo de rifteamento da porção oriental da margem norte brasileira. Rev Bras Geoc 17(2):196-207

Gacia-Cortez A, Carcavilla L (2009) Documento metodológico para laelaboracióndel inventario español de lugares de interés geológico (IELIG). Instituto Geológico y Minero de España

Grandgirard V (1995) Méthode pour la réalisation d'uninventaire de géotopes géomorphologiques. Ukpik, Cahiers de l'Institut de Géographie de l'Université de Fribourg, 10:121-137.

Grant C (2010) Towards a typology of visitor to geosites. Oral session presentation at the meeting of Second Global Geotourism Conference, Mulu, Malasia

Hose TA (1995) Selling the story of Britain's stone. Environ Int 10(2):16-17

Hose TA (2000) European Geotourism- geological interpretation and geoconservation promotion for tourists. In: Barretino D, Wibledon WAP, Gallego E (eds) Patrimonio geológico: conservación y gestión, Instituto Tec. Geominero de España, Madri, pp 98-107

IFEP - Instituto Fecomercio de Pesquisas Econômicas e Sociais da Paraíba (2014) Pesquisa Anual do Desempenho do Turismo na Região Metropolitana de João Pessoa- Pesquisa realizada junto aos turistas. http://www.fecomercio-pb.com.br/index. Acessed 06 Dec 2014

Jardim de Sá EF (1994) A Faixa Seridó (Província Borborema, NE do Brasil) e o seu significado geodinâmico na Cadeia Brasiliana/ Panafricana. PhD Thesis, Universidade de Brasília, Brasilia, Brazil.

Lima CC, Viviers MC, Moura JRS, Santo AM, Carmo, IO (1990) O Grupo Barreiras no Bacia Potiguar: relações entre o padrão de afloramento, estruturas pré-brasilianas e neotectonismo. In: Congresso Brasileiro de Geologia, 36, Natal. Anals. [Natal]. Sociedade Brasileira de Geologia

Lima FF (2008) Proposta metodológica para a inventariação do patrimônio geológico brasileiro. 2008. Dissertation, University of Minho

Miller JS (1991) Increasing visitor education through a tired approach to interpretation. Poster session presentation at the meeting of Visitor Studies Conference, New York, EUA

Nóbrega MA, Sá JM, Bezerra FHR, Hadler Neto JC, Iunes PJ (2005) The use of apatite fission track thermochronology to constrain fault movements and sedimentary basin evolution in northeastern Brazil. Radiat Meas 39(6):627-633

Pereira RF (2010) Geoconservação e desenvolvimento sustentável na Chapada Diamantina (Bahia, Brasil). Dissertation, University of Minho

Pereira LS, Amaral J (2014) Geoturismo urbano: análise da tipologia geológica e cultural da Capitania da Parahyba. Cad Est Pesq Tur 3(3):239-264

Pereira LS, Nogueira H (2015) Avaliação quantitativa do valor geoturístico do geopatrimónio - caso do Litoral Sul Paraibano, Brasil. Cad Geo 34:55-65

Pereira P, Pereira D (2012) Assessment of geosites tourism value in geoparks: the example of Arouca Geopark (Portugal). European Geoparks Conference, 11, Arouca: Proceedings... p. 231-232

Pereira LS, Vieira KG, Oliveira BL et al (2013a) The look ontheurban geoheritage of João Pessoa City: a guide to resignify rocks-document. Poster session presentation at the meeting of International Conference on Geography and Geosciences. Paris, France

Pereira LS, Oliveira BL, Vieira KG, et al. (2013b) Praça da Pedra: na example of a geohistoric monumento degraded in João Pessoa, PB. Poster session presentation at the meeting of International Conference on Geography and Geosciences. Paris, France

Pralong JP (2005) A method for assessing the tourist potential and use of geomorphological sites. Géomorphologie 3:189-196

Rivas V, Rix K, Fances E, Uceda AC, Brnensen D et al (1997) Geomorphological indicators for environmental impact assessment: consumable and non-consumable geomorphological resources. Geomorphology 18:169-182

Rodrigues ML, Fonseca AA (2008) Valorização do geopatrimônio no desenvolvimento sustentável em áreas rurais. Colóquio Ibérico em Estudos Rurais- Cultura, Inovação e Território, Coimbra. http:// www.sper.pt/oldsite/actas7cier/PFD/Tema\%20II/2_14.pdf. Acessed 22 Nov 2014

Rodriguez JL (2002) Atlas Escolar da Paraíba. Editora Grafset, João Pessoa

Ross JL (1985) Relevo brasileiro: uma nova proposta de classificação. Rev. Dep. Geog. USP, São Paulo, pp 25-39

Rybár P (2010) Assessment of attractiveness (value) of geotouristic objects. Acta Geoturistica 1(2):1321

Statistical yearbook of Tourism (2013) Ministry of Tourism. http:// dadosefatos.turismo.gov.br. Acessed 02 Dec 2014

Uceda AC (1996) Propuesta sobre criterios para laclasificación y catalogacióndel patrimônio geológico. In: El Patrimonio Geológico. Bases para suvaloración, protección, conservación y utilización, Ministerio de Obras Públicas,Transportes y Medio Ambiente, Madrid, pp 29-38

Ziemann DR, Figueiró AS (2017) Avaliação do potencial geoturístico no território da proposta Geoparque Quarta Colônia. Rev Dep Geog 34: $137-149$ 